\section{From foundling homes to day care: a historical review of childcare in Chile}

\author{
Desde la casa de expósitos a las salas cuna: \\ revisión histórica del cuidado infantil en Chile
}

\section{Desde a casa de crianças expostas para a creche: revisão histórica da puericultura no Chile}

\begin{abstract}
This article discusses significant changes in childcare policy and practice in Chile. We distinguish four specific periods of childcare history: child abandonment and the creation of foundling homes in the 19th century; efforts to reduce infant mortality and the creation of the health care system in the first half of the 20th century; an increasing focus on inequality and poverty and the consequences for child development in the second half of the 20th century; and, finally, the current focus on children's social and emotional development. It is concluded that, although Chile has achieved infant mortality and malnutrition rates comparable to those of developed countries, the country bears the mark of a history of inequality and is still unable to fully guarantee the health of children from the poorest sectors of society. Recent initiatives seek to improve this situation and put a strong emphasis on the psychosocial condition of children and their families.
\end{abstract}

Child Care; Child Welfare; Child Health Services
Rodrigo A. Cárcamo 1,2

René van der Veer 1

Harriet J. Vermeer 1

Marinus H. van IJzendoorn 1

\section{Resumen}

El artículo discute cambios significativos en políticas y prácticas del cuidado infantil en Chile. Se distinguen cuatro períodos históricos en los cuidados infantiles con las siguientes características: abandono infantil y la creación de la casa de expósitos en el siglo XIX; esfuerzos por disminuir la mortalidad infantil y la introducción de un sistema de salud en la primera mitad del siglo XX; un incremento en la atención de la desigualdad y la pobreza y sus consecuencias para el desarrollo infantil en la segunda mitad del siglo XX; y finalmente, una focalización en el desarrollo socioemocional de los niños. Se concluye que, aunque Chile ha alcanzado niveles de mortalidad infantil y desnutrición comparables a países desarrollados, todavía queda la marca de una historia de desigualdades que no permite garantizar completamente la salud de los niños más pobres. Recientes iniciativas tratan de mejorar esta situación y ponen un fuerte énfasis en las condiciones psicosociales de los niños y sus familias.

Cuidado del Niño; Bienestar del Niño; Servicios de Salud del Niño 


\section{Introduction}

Chile has achieved an infant mortality rate similar to that of developed countries. This favorable situation reflects the culmination of several changes made to childcare policy and practice based on the findings of scientific studies. The focus of childcare has shifted from prevention of infant mortality and morbidity toward the promotion of children's psychoemotional development. This review presents a concise, yet comprehensive account of childcare history in Chile that serves as a point of reference for specialists in social medicine, psychologists, and policy makers in Chile and other countries. Unlike previous studies 1,2, it covers a period of two hundred years and specifically concerns relevant scientific research. We discuss four critical periods of childcare history against the background of more general changes in health care focusing on the following main aspects: key policies; changes in childcare practice; and scientific research. The first period begins with the establishment of the Republic of Chile when child abandonment was very common and foundling homes first emerged. Later, in the first half of the twentieth century, the country began to implement health care policies aimed at reducing child mortality. During the third period, between the 1960s and 1990s, the first scientific publications on childcare began to emerge, inequality and poverty were identified as factors that cause malnutrition and stunted growth in children and the government laid the foundations of a more universal childcare system. The last period corresponds to the last decade, when childcare began to focus on improving children's social and emotional well-being. This period is characterized by a sharp increase in the number of research studies related to childcare.

\section{Method}

A search of articles resulting from relevant research studies conducted in Chile in the thematic areas of medicine, pediatrics, psychology, education, and health care was carried out using the Web of Science citation index. Abstracts, titles and keywords were searched using the tags "or" operators and the terms "child*", "infan*", "baby*", "babie*", "toddle*” and "Chile". The search yielded a sample of 1,849 papers which was reduced to 61 after applying the following exclusion criteria: (a) the focus of the study was not childcare; (b) the investigated variable was a specific disease; (c) the sample only included children aged over five years. Six of the excluded papers were considered particularly relevant and were added to the sample using the snowball method.

\section{Childcare in the nineteenth century: foundling homes}

Although reliable data on the early history of childcare in Chile is scarce, it is widely accepted that extreme poverty, social customs and cultural beliefs and practices, inadequate contraception, and religious traditions led to a number of unwanted children 3,4 . Previous to the emergence of foundling homes in the eighteenth century, unwanted infants were smothered, exposed to the elements, or left on the doorsteps of rich people's homes 5,6 .

The first foundling home, called La Casa de Huérfanos (the Orphans' House), was founded in Santiago de Chile in 1758 3,4. Its name hid the harsh fact that most of its inhabitants had been abandoned by their parents. In 1853, the French-Canadian congregation the Sisters of Providence began to run "La Casa" 3,4. The doctrine of the Catholic Church at the time strongly prohibited the use of contraception, abortion, and childbirth out of wedlock. Unmarried pregnant women were stigmatized and women who gave birth to an illegitimate child were pressured to abandon the infant. This and other factors, such as extreme poverty, led many unmarried mothers to leave their baby in the orphanage and $80 \%$ of the infants that passed through $L a$ Casa were illegitimate 3 . By 1912, Chile already had some 25 orphanages and La Casa was considered the largest and most important institution for abandoned children in the country 4 . Meza 3 estimated that more than 100,000 children were left in Chilean orphanages between 1770 and 1929.

Milanich 4, using historical letters and files, reconstructed children's arrival and "passage" through La Casa and found that a remarkably high proportion were abandoned. The same author 4 hypothesized that parents became more attached to their children after they had survived their first year of life. One possible reason for this is that very young children were seen as a greater economic burden to the family, compared to five or six-year-olds for example who could do simple manual tasks.

As in other countries, orphanages were not so much institutions where children grew up, but, more importantly, administrative bodies that played an important role in the redistribution of children 7,8,9. Orphanages provided the children with a semiofficial certificate stating that the child had been abandoned and allowing for their 
legal adoption. Many children stayed in La Casa only as long as it was necessary to arrange a legal adoption, which in some cases could be just a few days, or even hours 4 . Adoptive parents often requested a child when they needed a servant, maid or apprentice, or when they wished to have a child of their own as an heir or to care for them in their old age. The redistribution of infants and older children as unpaid servants in rich Catholic families was sanctioned and organized by the Catholic Church and was viewed as an act of charity and thus highly respected.

The redistribution of children was not without risk however. Infant mortality was very high in Chilean society as a whole and even higher in orphanages. The vulnerability of infants and costs of bringing up a child led many poor families to leave children at an orphanage with the hope that the child would survive, but also to avoid possible future funeral and burial costs 3 . Orphanages tried to contract wet nurses to keep the infants alive but, based on La Casa files, it is estimated that some $80 \%$ of abandoned infants did not survive ${ }^{4}$. Other studies found similar alarming death rates in orphanages in other countries during the same period 7,8,9,11,12. Against this social backdrop, the first quarter of the twentieth century saw a number of changes in Chilean society that led to an eventual reduction in the role of orphanages 4 .

\section{Childcare in the first half of the twentieth century: well-baby clinics}

In the beginning of the 20th century, Chile's government initiated social healthcare reforms to obtain what is called stage A in healthcare in an attempt to reduce infant mortality and increase life expectancy 13. A number of programs aimed at reducing malnutrition and mortality were introduced, such as the Gotas de Leche (drops of milk) program, which was implemented in 1901. This program was inspired by the Goutte de Lait program introduced by the Frenchman Budin in the consultation de nourrissons (well-baby clinic) that he founded in Paris in 1892. Well-baby clinics provided mothers with free sterilized cow milk, childcare advice and child health checks. Chile was one of the first countries in the world to replicate Budin's program 12,14,15,16. At the same time, the government of the then president Barros Luco (1910-1915), believing that existing programs were not enough to overcome the alarming infant mortality rates, organized the First National Conference on Child Protection, from which the idea to promote other measures such as maternity homes emerged 16 .
During this period, improvements were made to the general health system, such as the introduction of social insurance for workers in 1918. Although the majority of insurance funds offered only limited coverage for the treatment of specific diseases, exceptional cases, such as the Compulsory Workers Insurance Fund (Fondo de Seguro Obligatorio para Trabajadores), provided both curative and preventive healthcare specifically for mothers and infants 17 . Despite these improvements, the health system was severely criticized for its discriminatory nature by the then young Member of Parliament Salvador Allende. In 1938, the Preventive Medicine Act was passed which provided annual medical examinations for the early detection of several diseases in adults. During this period, the participation of local welfare boards (Juntas de Beneficiencia), supported by private contributions and the Church, also contributed to the development of the health system 17 . Different initiatives during the next decades contributed toward the development of a unified health system whose advantages were seen during the earthquake of 1938. However, it was not until 1952 that a new health system was created. The National Health System (Sistema Nacional de Salud, SNS) adopted the model of the British National Health Service founded in 1948, merging the functions of various public and private health systems. This system considerably broadened health coverage across society and succeeded in providing preventive and curative care to workers' spouses and their children, including those over the age of two years who were previously excluded from coverage 17 .

The goal of the SNS was to provide free health care, including maternity care and delivery, to all citizens. However, in practice, a private health system, primarily for white collar workers and other groups, such as the military, remained in existence, thus creating a hybrid system with compulsory health insurance and free care for manual workers and private care for privileged groups. From its inception, the SNS struggled with financial problems, as funding proved insufficient to meet increasing demand. Over the years, many attempts have been made to create a universal system fully funded by the state that includes all sectors of society, but to no avail (see below).

During this period, the reduction of the infant mortality rate (IMR) remained a priority goal. Numerous studies have analyzed the factors contributing to the decline in Chile's IMR, which is currently the lowest in South America (Figure 1). Contrary to claims $18,19,20$, the introduction of the SNS did not immediately result in a spectacular reduction of IMR. In 1960, eight years after the 
Figure 1

Child mortality under-five (IMR5), per 1,000 live births. Both sexes in South America, 1990-2010.

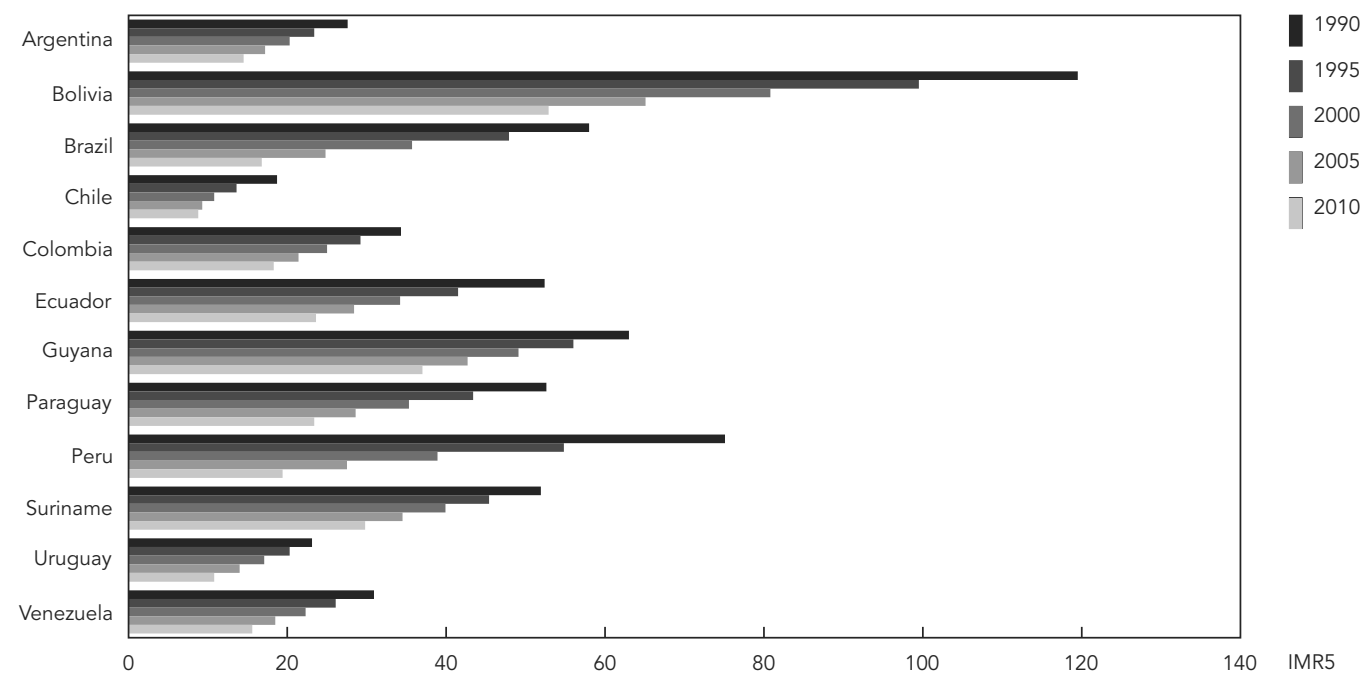

implementation of the SNS, the national IMR remained around 132 deaths per 1,000 live births, compared to 136 deaths per 1,000 live births in 1950 15,18,21. In fact, IMR had already shown a slow but steady decline before the introduction of the SNS. According to data provided by the World Health Organization (WHO), Chile's IMR reached a low of 7,7 deaths per 1,000 live births in 2011, while the under-five mortality rate was 8,7 deaths per 1,000 live births 22 . Several authors have claimed that this steady decline cannot be explained by steady economic growth because Chile has experienced several financial crises since the 1950s 23 . Important factors contributing to the decline of IMR were the provision of sewerage and fresh water supplies in cities and, more recently, rural areas 23 .

\section{Childcare in the late twentieth century: the struggle for universal health care}

This period was characterized by initiatives to provide more universal health care and greater equity in the health system. However, these initiatives suffered setbacks during the military regime due to attempts to commercialize the health system. At the same time, scientific research became more systematic 24 and oriented toward health outcomes, such as malnutrition and stunted growth.
The system was marked by unequal access since its inception in the early 1930s and Salvador Allende continued to oppose the system leading up to his rise to power. Allende was not alone in his opposition and efforts to create a more universal health system continued during the 1960s and 1970s. In 1968, for example, healthcare reforms proposed by Eduardo Frei Montalva's Christian Democratic government were met with strong resistance from medical doctors who feared a loss of income with the disappearance of the private healthcare system. Later, in the beginning of Allende's administration (1970 to 1973), renewed efforts were made to reform the health system. However, once again the idea to create a state-funded unified health system where all citizens have equal access met with fierce opposition from the medical lobby and plans were eventually aborted due to an increasingly adverse political climate 25 .

The most important change after the military coup d'état led by Pinochet in 1973 was the creation of the National System of Health Services (Sistema Nacional de Servicios de Salud, SNSS) replacing the SNS and creating 27 districts. Responsibility for primary care was delegated to municipalities creating a number of problems, such as loss of personnel status, disorganization of epidemiological files and longer waiting lists. Furthermore, the creation of Isapres (Instituciones de Salud Previsional) established an element 
of private health insurance in the system which, together with other gradual reforms, caused unequal access to health care 25 . In the 1990s however health policies took a turn for the better for low income groups and primary health care was once again provided free of charge, and economically vulnerable women received greater financial support and free healthcare before and after delivery 19,25. This first period of the return to democracy was also characterized by a major increase in investment in public health and health spending rose to levels that were eight times higher than those in the 1980s. The percentage of the Gross National Income devoted to healthcare, which during the dictatorship had been reduced to $0.85 \%$, rose to $6.5 \%$; however the majority of this funding went to the private system 25 .

Studies showed the significant progress in the fight against IMR and malnutrition, while increasingly accurate statistics revealed the persistent problem of social inequality. Various authors showed that IMR was a function of social class, geographical region, and per capita income $25,26,27,28,29$, exposing the continuing role of socioeconomic conditions in public health in Chile. IMR was much higher in poor rural areas than in more affluent communities 25,26,27,30. Labra 25 also argued that inequalities were accentuated by the neoliberal reforms that began in the mid1970s based on the view that poverty was the result of personal failure.

The consequences of socioeconomic inequality for childcare and child health were the subject of a number of studies 26,27,28,31,32,33,34,35, $36,37,38,39,40,41,42,43,44,45,46,47,48,49$. McCormicketal. 28 concluded that factors related to urbanization and literacy were associated with the decline in IMR. Herthel-Fernández et al. 27 highlighted a strong association between child mortality and low levels of maternal education and paternal occupation. Donoso 26 observed an association between child mortality and family income, showing that IMR in wealthier parts of Santiago de Chile was similar to that of developed countries (5.6 per 1,000 live births), while rates in poorer neighborhoods were comparable to national levels between 1984 and 1990. In a study of adolescent mothers, Buvinic et al. 37 found that marital status and professional occupation of mothers were strong predictors of financial income and capacity to care for children. The study showed that adolescent mothers that did not receive support from the father of their child were at greater risk and, as a consequence, often had to enter the labor market under unfavorable conditions, thus leading to what Buvinic et al. 37 call the "reproduction of poverty".
Following healthcare developments, such as the sharp decrease in IMR, new investigations emerged in the 1990s focusing on child nutrition and stunted growth, particularly among the poor $38,39,40,49,50,51,52$. It was shown that malnutrition during the first year of life had a negative impact on cognitive level, IQ scores, and school results $38,40,44,51$. In addition, Valenzuela 49,52 found a significant association between malnutrition and low maternal sensitivity and a high risk of developing an anxious mother-child attachment in low-income families. Other results indicated that recovery from the cognitive and physical effects of malnutrition was better in children who grew up with their biological parents than in institutionalized children 39,45 . In a study conducted to reveal the variables associated with stunted growth in school children, Amigo et al. 50 showed that environmental factors, such as paternal alcoholism, lack of good health care, poor hygiene, malnutrition, and a short breastfeeding period, were factors contributing to stunted growth. This led to the introduction of programs to promote breastfeeding 31,53,54, which seem to have had positive effects, particularly in rural areas 55 . Adolescent mothers were found to be most likely to discontinue breastfeeding early 56 .

Another important aspect of the sociocultural development of children is ethnic background. For example, several studies have analyzed physical growth and mental development in Mapuche children, the largest ethnic group in Chile that represents $4.6 \%$ of the total population. Bustos et al. 35,36 and Amigo et al. 33 reported that stunted growth and low weight in Mapuche children were not so much the result of hereditary differences but of conditions of poverty, and under ideal circumstances there should be no difference between anthropometric measures of indigenous and non-indigenous children, which is consistent with the results of studies reported in the WHO Child Growth Standards 58.

\section{Childcare in the last decade: quality of living conditions and social and emotional wellbeing}

Child care policies in the last decade have been aimed at improving children's living conditions. Research has focused on evaluating the influence of the family and school environment on children's emotional development and attachment.

One of the most important developments was the introduction of the program Chile Grows with You (Chile Crece Contigo) in 2007. This program formed one of the key pillars of social protection policies introduced by the Bachelet 
administration 59. The program was inspired by similar programs in the United States and United Kingdom, such as Head Start, and aimed to cover the period from gestation to preschool. Presently, the program is mainly geared to the most vulnerable groups of society, in which primary caregivers are subject to a high risk of mental health problems 60 .

The program focuses not only on nutrition and physical health but also involves other initiatives such as early stimulation programs, improvements in children's physical environment, parent education, guidelines for providing biopsychosocial support from pregnancy onwards 59 . The aim is to improve both children's physical and psychoemotional wellbeing to ensure greater equality of opportunity to improve development 59. In their recent evaluation report on Chile Crece Contigo, Bedregal et al. 60 highlight the family and social aspects of children's environment, such as the health of the principal caregivers (mainly mothers), and observed a high prevalence of risk factors such as low levels of social participation, stress and family violence.

The present focus of the early stimulation programs and health and child care policies in general clearly shows a shift from measures typical of developing countries on the road to overcoming poverty (the fight against high IMR, malnutrition and stunted growth) to those typical of developed countries, where investment in children's well-being and equal educational opportunities take priority. There is no doubt that these efforts contributed enormously to the improvement of both health care and early education.

As mentioned above, research studies have focused more on the cognitive and social and emotional development of children. Various studies analyzed specific variables related to the family environment, such as the use of physical punishment. It was found, for example, that a rebellious attitude was the most frequent reason for physical punishment by parents of children attending private schools, while poor school results were the main reason for physical punishment by parents of children attending public schools 61,62. With respect to maternal depression and its relation to the mother-child relationship, several studies found that in poorer families child health risks are related more to the mother's psychological characteristics than other factors, such as maternal malnutrition, education and lactation 33,63,64,65. In this respect, Fritsch et al. 64 observed a high prevalence of depression in mothers of small children in Chile and Wolf et al. 65 found that half of the children whose mothers suffered from depression had behavioral and emotional problems. Farkas \& Valdés 66 investigated the relationship between maternal stress and selfefficacy in a sample of high risk children under nine months of age attending day care centers and found that family characteristics such as the number of people living in the household, per capita income, and mother's age were associated with maternal stress and perceived self-efficacy.

There are few publications about the quality of the family environment in the Chilean scientific literature. A study by Sanhueza $48 \mathrm{dem}$ onstrated that the quality of stimulation in the family is a more relevant predictor for a child's psychomotor development than economic conditions. Based on the results of the Home $\mathrm{Ob}$ servation for Measurement of the Environment (HOME), he also noted that levels of stimulation were medium-high in $63 \%$ of families and high in $32 \%$ of families 67 . These results are consistent with a previous study using HOME conducted by Bustos et al. 68 which observed adequate levels of child stimulation in families and higher levels among children who attend private schools.

Different aspects of the quality of preschool education and factors contributing to educational achievement have also been the subject of recent studies 69,70 . Evaluations of the preschool learning environment using internationally tested instruments such as the Infant/Toddler Environment Rating Scale-Revised Edition 71, Early Childhood Environment Rating Scale 72, and School-Age Care Environment Rating Scale 73, were reported in only two studies, which explains why reliable information about the quality of day care centers is relatively scarce in Chile. The results of these studies showed that quality levels in the majority of day care centers (newborns to two-year-olds) and preschools (five to six-yearolds) were low or medium, with higher levels in private centers. With respect to four to five-yearolds, average levels in state day care centers belonging to the National Board of Preschools (Junta Nacional de Jardines Infantiles, JUNJI) were higher than in private day care centers. However, the highest levels of quality were found in private day care centers 69,70.

Research interest in children's social and emotional development is recent. With the exception of two papers by Valenzuela 49,52 , all studies found were published in the last five years $74,75,76,77,78,79,80,81,82$. The investigations carried out by Valenzuela 49,52 were the first in Chile to utilize the Strange Situation Procedure (SSP) to assess mother-child attachment. Furthermore, this author was the first to find an association between mother and child nutrition and the quality of infant-mother attachment in a high-risk sample and showed that severe malnutrition leads to a greater risk of developing anxious/resistant 
attachment and is related to low maternal sensitivity. Recent studies have shown that the distribution of attachment classifications in Chile's population is comparable to international patterns. Roughly two-thirds of children experience secure attachment, and attachment security is greater in boys than in girls 78 and in children born through vaginal delivery. It was also found that attending day care centers was positive for the development of children in terms of the quality of social interaction 81 .

These results contribute to the current political debate about lengthening the duration of maternity leave and encouraging the use of day care at a time when female labor force participation is encouraged as a way to help reduce poverty. Currently, about $43 \%$ of women in Chile are in the labor market and the number of children aged over three months in day care centers increased fivefold between 2006 and 2009. Medrano showed that in 2009 approximately $37.4 \%$ of preschoolers were receiving nonmaternal care, most of which on a full-time basis 83 . This and other issues, such as the quality of day care and its effects on children's cognitive development and mother-child attachment, is the subject of heated debate. Although research focusing on these issues in Chile in underway, the number of studies remains insufficient.

\section{Conclusions}

This study discussed childcare policy and practice, and scientific research in four distinct periods of Chile's history. The first period was characterized by the creation of a system to deal with abandoned children. Efforts during this period focused on decreasing infant mortality rates and increasing life expectancy. In the following period efforts focused on improving children's basic living conditions and the main objectives were the improvement of child nutrition, disease prevention, and the fight against stunted growth. The third period coincided with the creation of a number of medical schools and research in the field of social sciences began to focus on child well-being. Childcare issues became a topic of intense political debate. However, this debate was abruptly interrupted by the military regime, which introduced a market oriented health care system. Recently, since Chile's return to democracy, the emphasis has shifted to promoting children's social and emotional development, as in other countries 84 . This period is what Kaempffer \& Medina 13 call stage $\mathrm{C}$ in the historical development of health care in developing countries characterized by overcoming eco- nomic problems, delivering sanitation solutions and the introduction of free basic health care. The contemporary program Chile Crece Contigo, which focuses on the promotion of new healthy habits, secure attachment and the improvement of children's living conditions, is an example of recent developments. The most recent period is also characterized by an important increase in empirical studies concerning these issues and associated developments in childcare policy and practice.

It is evident that a number of variables reviewed by this study, including infant mortality, malnutrition, maternal education, stunted growth, ethnicity, quality of the home environment, maternal stress and sensitivity, are closely related and cannot be easily isolated. The relationship between these variables partly reflects a social structure inherited from colonial times characterized by strong social division and economic inequality. This situation condemns a substantial percentage of Chile's population to live in conditions that have an adverse effect on children's well-being, similar to other Latin American countries such as Argentina, Brazil, Bolivia and Nicaragua. Research has shown that a number of distal, intermediate and proximate factors are predictors of child health indicators such as infant mortality, malnutrition and stunted growth. Living conditions are important factors, especially in rural areas without adequate sanitation and sewerage, and piped water. Income and education play a role since they are determinants of nutrition, awareness and understanding of hygiene measures, number of siblings, and access to medical care. Finally, the introduction of comprehensive primary health care services providing preventive and curative care has proved effective in a number of countries such as Brazil 85,86,87,88,89.

It is still unclear whether the new government policy of promoting full-time day care for infants aged over three months will alleviate these problems and thus break the circle of inherited poverty. Attending day care centers may promote social and intellectual skills, but the effects of full-time day care on attachment are a cause for concern. Early and full-time day care attendance may hinder the development of secure motherchild attachment, especially where quality of day care and maternal sensitivity are low 90,91. This is worrying because insecure mother-child attachment may negatively affect children's future emotional and cognitive development. Recent research interest in Chile in issues relating to attachment is promising but a deeper understanding of the long-term consequences of the new childcare policy is necessary. 


\section{Resumo}

O artigo discute as mudanças significativas nas politicas e práticas sobre cuidado infantil, no Chile. Quatro períodos históricos foram estabelecidos, levando em consideração as seguintes características: abandono da criança e a criação de casas de crianças expostas no século XIX; esforços para reduzir a mortalidade infantil e a implementação de sistemas de cuidados de saúde na primeira metade do século XX; maior atenção à desigualdade e à pobreza, bem como as consequências que estas ações trouxeram para o desenvolvimento das crianças, na segunda metade do século XX; e, finalmente, a ênfase no desenvolvimento socioemocional das crianças. Conclui-se que, embora o Chile tenha alcançado taxas de mortalidade infantil e de desnutrição comparáveis às dos países desenvolvidos, há, ainda, indicadores históricos de desigualdade, que resultam na redução das garantias de acesso à saúde pública das crianças mais pobres. Iniciativas recentes procuram melhorar a situação e colocar a ênfase sobre as condições psicossociais de crianças e suas famílias.

Cuidado da Criança; Bem-Estar da Criança; Serviços de Saúde da Criança

\section{Contributors}

R. A. Cárcamo contributed to study conception and design, data collection, analysis and interpretation, drafting of this article and final approval of the published version. R. van der Veer contributed to study conception and design, data collection, analysis and interpretation, drafting of this article and revising it critically for important intellectual content, and final approval of the published version. H. J. Vermeer contributed to study conception and design, data analysis and interpretation, revising the article critically for important intellectual content, and final approval of the published version. M. H. van IJzendoorn contributed to study conception and design, interpretation of data, revising the article critically for important intellectual content, and final approval of the published version.

\section{Acknowledgments}

This study was made possible by a grant awarded to the first author by CONICYT, Chile (Becas Chile).

\section{References}

1. Milanich NB. Children of fate. Childhood, class, and the state in Chile, 1850-1930. Durham/London: Duke University Press; 2009

2. Flores J. Historia de la infancia en el Chile republicano, 1810-2010. 2a Ed. Santiago de Chile: Ocho Libros Editores; 2010.

3. Meza RS. Orphans and family disintegration in Chile: the mortality of abandoned children, 17501930. J Fam Hist 1991; 16:315-29.

4. Milanich N. The Casa de Huerfanos and child circulation in late-nineteenth-century Chile. J Soc Hist 2004; 38:311-40.

5. Cunningham H. Children and childhood in Western society since 1500. Edinburgh Gate: Pearson Education; 1995.

6. Stearns P. Childhood in world history. $2^{\text {nd }}$ Ed. New York: Routledge; 2011.
7. Fuchs R. Abandoned children: foundlings and child welfare in nineteenth-century Paris. Albany: SUNY Press; 1984.

8. Ransel DL. Mothers of misery: child abandonment in Russia. Princeton: Princeton University Press; 1988.

9. Sherwood J. Poverty in eighteenth-century Spain: the women and children of the Inclusa. Toronto: University of Toronto Press; 1988.

10. Ariès P. Centuries of childhood. London: Pimlico Edition; 1996.

11. Hrdy S. Mother nature: a history of mothers, infants, and natural selection. New York: Pantheon; 1999.

12. Wickes IG. A history of infant feeding: part III. Eighteenth and nineteenth century. Arch Dis Child 1953; 28:332-40. 
13. Kaempffer A, Medina E. La salud infantil en Chile durante la década de los setenta. Rev Chil Pediatr 1982; 53:468-80.

14. Dyhouse C. Working-class mothers and infant mortality in England, 1895-1914. J Soc Hist 1978; 12:248-67.

15. Rosselot J. Salud infantil en Chile y el rol de la colaboración internacional. Rev Chil Pediatr 1982; 53:481-90.

16. Schonhaut B. "Profilaxia del abandono": cien años de protección de la infancia en Chile. Rev Chil Pediatr 2010; 81:304-12.

17. Hall TL, Diaz S. Social security and health care patterns in Chile. Int J Health Serv 1971; 1:362-77.

18. Kaempffer A. Evolución de la salud materno infantil en Chile, 1952-1977. Rev Méd Chil 1977; 105:680-6.

19. Szot J. Mortalidad infantil e indicadores económicos en Chile: 1985-1999. Rev Méd Chil 2002; 130:107-12.

20. Viel B. Family planning in Chile. J Sex Res 1967; 3:284-91.

21. Jimenez J, Romero MI. Reducing infant mortality in Chile: success in two phases. Health Aff 2007; 26:458-65.

22. World Health Organization. Child mortality 19902011. http://gamapserver.who.int/gho/interac tive_charts/MDG4/atlas.html (accessed on 13/ Mar/2013).

23. Monckeberg F, Valiente S, Mardones F. Infant and pre-school nutrition: economical development, versus intervention strategies. The case of Chile. Nutr Res 1987; 7:327-42.

24. Riley P. The health officer and health education: functions of health educators. Am J Public Health 1956; 42:679-86.

25. Labra ME. La reinvención neoliberal de la inequidad en Chile. El caso de la salud. Cad Saúde Pública 2002 ; 18:1041-52.

26. Donoso E. Desigualdad en mortalidad infantil entre las comunas de la provincia de Santiago. Rev Méd Chil 2004; 132:461-6.

27. Hertel-Fernández AW, Giusti AE, Sotelo JM. The Chilean infant mortality decline: improvement for whom? Socioeconomic and geographic inequalities in infant mortality, 1990-2005. Bull World Health Organ 2007; 85:798-804.

28. McCormick MC, Shapiro S, Horn SD. The relationship between infant mortality rates and medical care and socio-economic variables, Chile 19601970. Int J Epidemiol 1979; 8:145-54.

29. Hollstein RD, Vega J, Carvajal Y. Desigualdades sociales y salud: nivel socioeconómico y mortalidad infantil en Chile, 1985-1995. Rev Méd Chil 1998; 126:333-40.

30. Medina E, Kaempffer A. Tendencias y características de la mortalidad chilena 1970-2003. Rev Méd Chil 2007; 135:240-50.

31. Alvarado R, Zepeda A, Rivero S, Rico N, López S, Díaz S. Integrated maternal and infant health care in the postpartum period in a poor neighborhood in Santiago, Chile. Stud Fam Plann 1999; 30: 133-41.

32. Alvarez ML, Wugaft F, Salazar ME. Health and poverty in families with children. Pediatr Res 1988; 23:649.
33. Amigo H, Bustos P, Kaufman JS. Absence of disparities in anthropometric measures among Chilean indigenous and non-indigenous newborns. BMC Public Health 2010; 10:1-8.

34. Araya M, Espinoza J, Zeger B, Cruchet S, Brunser O, Humphreys D, et al. Altered maternal psychological profile as health risk factor in poor urban infants. Acta Paediatr 1996; 85:1213-6.

35. Bustos P, Amigo H, Muñoz SR, Martorell R. Growth in indigenous and nonindigenous Chilean schoolchildren from 3 poverty strata. Am J Public Health 2001; 91:1645-9.

36. Bustos P, Muñoz S, Vargas C, Amigo H. Evolution of the nutritional situation of indigenous and nonindigenous Chilean schoolchildren. Ann Hum Biol 2009; 36:298-307.

37. Buvinic M, Valenzuela JP, Molina T, González E. The fortunes of adolescent mothers and their children: the transmission of poverty in Santiago, Chile. Popul Dev Rev 1992; 18:269-97.

38. Castillo M, Cortes F, De Andraca I. Growth delay in school age children of low socioeconomic level: its impact on cognitive functioning. Pediatr Res 1993; 33:661.

39. Colombo M, de la Parra A, López I. Intellectual and physical outcome of children undernourished in early life is influenced by later environmental conditions. Dev Med Child Neurol 1992; 34:611-22.

40. De Andraca I, Castillo M, Cortes F. Stunting in school age children of low socioeconomic level (SEL) cognitive performance. Pediatr Res 1996; 39:370.

41. González R, Requejo JH, Nien JK, Merialdi M, Bustreo F, Betran AP. Tackling health inequities in Chile: maternal, newborn, infant, and child mortality between 1990 and 2004. Am J Public Health 2009; 99:1220-6.

42. Ivanovic DM, Leiva BP, Pérez HT, Olivares MG, Díaz NS, Urrutia MS, et al. Head size and intelligence, learning, nutritional status and brain development. Head, IQ, learning, nutrition and brain. Neuropsychologia 2004; 42:1118-31.

43. Ivanovic DM, Perez HT, Olivares MG, Diaz NS, Leyton LD, Ivanovic RA. Scholastic achievement: a multivariate analysis of nutritional, intellectual, socioeconomic, sociocultural, familial, and demographic variables in Chilean school-age children. Nutrition 2004; 20:878-89.

44. Ivanovic D, Rodríguez MDP, Pérez H, Alvear J, Díaz $\mathrm{N}$, Leyton B, et al. Twelve-year follow-up study of the impact of nutritional status at the onset of elementary school on later educational situation of Chilean school-age children. Eur J Clin Nutr 2008; 62:18-31.

45. Ivanovic DM, Rodríguez MDN, Pérez HT, Alvear JA, Almagia AF, Toro TD, et al. Impact of nutritional status at the onset of elementary school on academic aptitude test achievement at the end of high school in a multicausal approach. Br J Nutr 2009; 102:142-54

46. Prieto M, Scott R. Preschool learning profiles of poor and middle-class chilean children. J Soc Psychol 1986; 126:381-8. 
47. Rodríguez S, Lira MI, Montenegro H. Programa de estimulación precoz para niños de nivel socioeconómico bajo, entre 0 y 2 años. Plan piloto. Rev Latinoam Psicol 1975; 7:327-32.

48. Sanhueza AD. Psychomotor development, environmental stimulation, and socioeconomic level of preschoolers in Temuco, Chile. Pediatr Phys Ther 2006; 18:141-7.

49. Valenzuela M. Maternal sensitivity in a developing society: the context of urban poverty and infant chronic undernutrition. Dev Psychol 1997; 33: 845-55.

50. Amigo H, Bustos P, Leone C, Radrigán ME. Growth deficits in Chilean school children. J Nutr 2001; 131:251-4.

51. Ivanovic DM, Leiva BP, Perez HT, Inzunza NB, Almagia AF, Toro TD, et al. Long-term effects of severe undernutrition during the first year of life on brain development and learning in Chilean highschool graduates. Nutrition 2000; 16:1056-63.

52. Valenzuela M. Attachment in chronically underweight young-children. Child Dev 1990; 61: 1984-96.

53. Campos M, Márquez F, Wilson L. Teaching chilean mothers to massage their full-term infants. Effects on maternal breast-feeding and infant weight gain at age 2 and 4 months. J Perinat Neonatal Nurs 2010; 24:172-9.

54. Uauy R, De Andraca I. Human-milk and breastfeeding for optimal mental development. J Nutr 1995; 125(8 Suppl):S2278-80.

55. Valdés V, Pérez A, Labbok M, Pugin E, Zambrano I, Catalan S. The impact of a hospital and clinicbased breast-feeding promotion program in a middle-class urban environment. J Trop Pediatr 1993; 39:142-51.

56. Barría RM, Santander G, Victoriano T. Factors associated with exclusive breastfeeding at 3 months postpartum in Valdivia, Chile. J Hum Lact 2008; 24:439-45.

57. Alarcón AM, Nahuelcheo Y. Creencias sobre el embarazo, parto y puerperio en la mujer mapuche: conversaciones privadas. Chungará, Revista de Antropología Chilena 2008; 40:193-202.

58. World Health Organization. WHO child growth standards: length/height-for-age, weight-for-age, weight-for-length, weight-for-height and body mass index-for-age. Methods and development. http://www.who.int/childgrowth/standards/tech nical_report/en/index.html (accessed on 13/Mar/ 2013).

59. Saracostti M. Constructing Chile's social protection system: from early childhood to old age. Int Soc Work 2010; 53:568-74.

60. Bedregal P, Hernandez V, Prado P, Castanon C, Mingo V, de la Cruz R. Hacia la evaluación de "Chile Crece Contigo": resultados psicosociales del estudio piloto. Rev Méd Chil 2010; 138:791-3.

61. Chávez C, Castillo M, Lozoff B. Chaos in the family environment and violent behaviour towards children. Pediatr Res 2008; 63:23.

62. Vargas NA, Lopez D, Perez P, Zuniga P, Toro G, Ciocca P. Parental attitude and practice regarding physical punishment of school-children in Santiago de Chile. Child Abuse Negl 1995; 19:1077-82.
63. Clark KM, Castillo M, Calatroni A, Walter T, Cayazzo M, Pino P, et al. Breast-feeding and mental and motor development at $51 / 2$ years. Ambul Pediatr 2006; 6:65-71.

64. Fritsch R, Montt ME, Solís J, Pilowsky D, Rojas MG. ¿Cómo es la salud mental de los hijos de madres deprimidas consultantes a servicios de atención primaria? Rev Méd Chile 2007; 135:602-12.

65. Wolf AW, De Andraca I, Lozoff B. Maternal depression in three Latin American samples. Soc Psychiatry Psychiatr Epidemiol 2002; 37:169-76.

66. Farkas C, Valdés N. Maternal stress and perceptions of self-efficacy in socioeconomically disadvantaged mothers: an explicative model. Infant Behav Dev 2010; 33:654-62.

67. Caldwell BM, Bradley RH. Home observation for measurement of the environment: HOME administration manual. Homewood: Dorsey Press; 1984.

68. Bustos C, Herrera M, Mathiesen M. Calidad del ambiente del hogar: inventario HOME como un instrumento de medición. Estudios Pedagógicos 2001; 27:7-22.

69. Herrera MO, Mathiesen ME, Merino JM, Recart I. Learning contexts for young children in Chile: process quality assessment in preschool centres. Int J Early Years Educ 2005; 13:13-27.

70. Villalón M, Suzuki E, Herrera M, Mathiesen M. Quality of chilean early childhood education from an international perspective. Int J Early Years Educ 2002; 10:49-59.

71. Harms T, Cryer D, Clifford RM. Infant/toddler environment rating scale revised. New York: Teachers College Press; 2003.

72. Harms T, Clifford RM, Cryer D. Early childhood environment rating scale. New York: Teachers College Press; 1980.

73. Harms T, Jacobs EV, White DR. School age care environment rating scale, SACERS. New York: Teachers College Press/Columbia University; 1996.

74. Araneda ME, Santelices MP, Farkas C. Building infant-mother attachment: the relationship between attachment style, socio-emotional well-being and maternal representations. J Reprod Infant Psychol 2010; 28:30-43.

75. De Aguiar S, Santelices MP, Pérez J. Apego, sensibilidad paterna y patrón de interacción del padre con su primer bebé. Rev Argent Clín Psicol 2009; 18:51-8.

76. Lecannelier F, Kimelman M, González L, Nuñez C Hoffmann M. Evaluación de patrones de apego en infantes durante su segundo año en dos centros de atención de Santiago de Chile. Rev Argent Clín Psicol 2008; 17:197-207.

77. Lecannelier F, Undurraga V, Olivares AM, Rodriguez J, Nunez JC, Hoffmann M, et al. Estudio de eficacia sobre dos intervenciones basadas en el fomento del apego temprano en díadas madre-bebé provenientes de la región Metropolitana en Santiago de Chile. Rev Argent Clín Psicol 2009; 18:143-55.

78. Pierrehumbert B, Santelices MP, Ibanez M, Alberdi M, Ongari B, Roskam I, et al. Gender and attachment representations in the preschool years comparisons between five countries. J Cross Cult Psychol 2009; 40:543-66. 
79. Quezada V, Santelices MP. Apego y psicopatología materna: relación con el estilo de apego del bebé al año de vida. Rev Latinoam Psicol 2010; 42:53-61.

80. Santelices MP, Olhaberry M, Araneda ME, Tapia C, Perez-Salas CP. Estudio de l evolución de las representaciones y apego materno, en un grupo de embarazadas primigestas chilenas. Rev Argent Clín Psicol 2007; 16:219-29.

81. Santelices MP, Olhaberry M, Perez-Salas CP, Carvacho C. Comparative study of early interactions in mother-child dyads and care centre staff-child within the context of Chilean crèches. Child Care Health Dev 2010; 36:255-64.

82. Santelices MP, Guzmán M, Aracena M, Farkas C, Armijo I, Pérez-Salas CP, et al. Promoting secure attachment: evaluation of the effectiveness of an early intervention pilot programme with motherinfant dyads in Santiago, Chile. Child Care Health Dev 2011; 37:203-10.

83. Medrano PA. Public day care and female labor force participation: evidence from Chile. http://www. econ.uchile.cl/uploads/publicacion/25d848f10435-4691-9623-b20cff7a36aa.pdf (accessed on 12/Mar/2013).

84. Clerkx LE, Van IJzendoorn MH. Child care in a Dutch context: on the history, current status, and evaluation of nonmaternal child care in the Netherlands. In: Lamb ME, Sternberg KJ, Hwang C-P, Broberg AG, editors. Child care in context: crosscultural perspectives. Hillsdale: Lawrence Erlbaum; 1992. p. 55-79.
85. Alves D, Belluzzo W. Infant mortality and child health in Brazil. Econ Human Biol 2004; 2:391-410.

86. Behrman JR, Skoufias E. Correlates and determinants of child anthropometrics in Latin America: background and overview of the symposium. Washington DC: Inter-American Development Bank; 2004. (Research Network Paper, R-496).

87. Victora CG, Barros FC. Infant mortality due to perinatal causes in Brazil: trends, regional patterns and possible interventions. São Paulo Med J 2001; 119: 33-42.

88. Macinko J, Guanais FC, Marinho de Souza M. Evaluation of the impact of the Family Health Program on infant mortality in Brazil, 1990-2002. J Epidemiol Community Health 2006; 60:13-9.

89. Wolfe BL, Behrman JR. Determinants of child mortality, health, and nutrition in a developing country. J Dev Econ 1982; 11:163-93.

90. NICHD Early Child Care Research Network. The effects of infant child care on infant mother attachment security: results of the NICHD Study of Early Child Care. Child Dev 1997; 68:860-79.

91. NICHD Early Child Care Research Network. Child care and mother-child interaction in the first three years of life. Dev Psychol 1999; 35:1399-413.

Submitted on 03/Apr/2013

Final version resubmitted on 14/Nov/2013

Approved on 13/Jan/2014 